Jurnal Kesehatan Perintis (Perintis's Health Journal) 8 (1) 2021: 1-11

Contents list available at JKP website

PERINTIS Jurnal Kesehatan Perintis (Perintis's Health Journal)

Journal homepage: https://jurnal.stikesperintis.ac.id/index.php/JKP

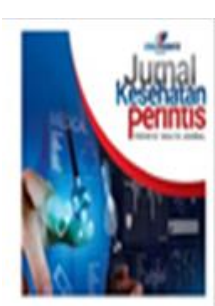

Literature Review

\title{
Komunikasi Keluarga Dan Pola Asuh Dengan Kecerdasan Emosional Anak Usia 5 - 18 Tahun
}

\author{
Neila Sulung ${ }^{1^{*}}$, Genta Sakti ${ }^{2}$ \\ 1)Universitas Fort De Kock Bukittinggi, Sumatera Barat, Indonesia \\ ${ }^{2)}$ Institut Agama Islam Negeri Bukittinggi, Sumatera Barat, Indonesia
}

\section{Article Information :}

Submission: Jun 8, 2021; Revised: Jun 15, 2021; Accepted:Jun 28, 2021; Available online: Jun 30,2021

*Corresponding author : neilasulung_64@yahoo.com

\begin{abstract}
ABSTRAK
Kecerdasan emosional anak-anak sangat penting untuk perkembangan pribadi anak-anak secara menyeluruh. Perkembangan kecerdasan emosional. Adapun tujuan penelitian ini adalah: melihat dampak komunikasi dalam keluarga dan pola asuh orangtua terhadap kecerdasan emosional anak usia 5-18 Tahun. Metodologi penelitian dengan melakukan literature review dari beberapa artikel baik internasional maupun nasional yang dicari dengan mempergunakan google scholar dan sciencedirect, mengisihkan 72 artikel dengan kata kunci Pola asuh, komunikasi dalam keluarga dan kecedasan emosional. yang terdiri dari 36 internasional dan 36 jurnal nasional setelah dilakukan seleksi sesuai kata kunci yang dianalisis 18 artikel, yang terdiri dari 8 artikel internasional dan 10 artikel Nasional penelusuran dengan mempergunakan google scholar dan sciencedirect dengan desain penelitian kuantitatif dan kualitatif. Hasil penelitian: Bahwa pola asuh dan komunikasi keluarga sangat berpengaruh terhadap kecerdasan emosional anak. Kesimpulan: pola asuh demoktratis akan membentuk kecedasan yang positif dan pola komunikasi dengan keluarga yang sangat membantu kecerdasan emosional lebih menekan pada pada durasi waktu interaksi anak dan orang tua. Disarankan pada orang tua untuk memperhatikan pola asuh dan komunikasi keluraga untuk mendapat anak yang cerdas secara emosional
\end{abstract}

Kata Kunci: pola asuh, komunikasi keluarga kecerdasan emosional

\begin{abstract}
Children's emotional intelligence is very important for children's personal development as a whole. Development of emotional intelligence. The objectives of this study are: to see the impact of communication in the family and parenting patterns on the emotional intelligence of children aged 5-18 years. The research methodology was carried out by conducting a literature review of several articles, both international and national, which were searched using Google Scholar and ScienceDirect, filling in 72 articles with the keywords Parenting, communication in the family and emotional intelligence. which consists of 36 international and 36 national journals after being selected according to keywords which were analyzed by 18 articles, consisting of 8 international articles and 10 national articles, searches using Google Scholar and ScienceDirect with quantitative and qualitative research designs. Research Results: That parenting and family communication is very influential on children's emotional intelligence,
\end{abstract}


Conclusion: democratic parenting will form positive intelligence and communication patterns with families which really help emotional intelligence put more emphasis on the duration of interaction between children and parents. Recommended: for parents to pay attention to parenting and family communication to get emotionally intelligent children

\section{Keywords: parenting, emotional intelligence family communication}

\section{LATAR BELAKANG}

Kecerdasan emosi sebagai suatu kecerdasan sosial yang berkaitan dengan kemampuan individu dalam memantau baik emosi dirinya maupun emosi orang lain, dan juga kemampuannya dalam membedakan emosi dirinya dengan emosi orang lain dimana kemampuan ini digunakan untuk mengarahkan pola pikir dan perilaku anak. Pola asuh adalah sikap atau tindakan yang diterapkan orang tua terhadap anak melalui interaksi baik verbal maupun non verbal pada berbagai aspek perkembangan anak. Sedangkan komunikasi keluarga atau komunikasi antarpribadi yang paling sederhana dapat kita amati di dalam keluarga. Suatu keluarga terdiri dari pribadipribadi yakni ayah, ibu, dan anak. Peranan anggota keluarga dalam menciptakan suasana keluarga kuat sekali. Masingmasing pribadi diharapkan tahu peranannya di dalam keluarga. Kedua hal diatas pola asuh dan komunikasi keluarga sangat di pentingkan untuk menstimulus perkembangan emosional anak. Demikian juga menurut Steiner (1997) kecerdasan emosional adalah kemampuan untuk memahami emosi diri sendiri dan orang lain, serta mengetahui bagaimana kondisi emosional diri untuk meningkatkan etika sebagai kekuatan pribadi. Sementara Cooper dan Sawaf (1998) juga mengatakan bahwa kecerdasan emosional berkaitan dengan kemampuan individu untuk merasakan, memahami, dan secara selektif menerapkan daya dan kepekaan emosi sebagai sumber energi dan pengaruh manusia. Kecerdasan emosional membutuhkan perasaan pengawasan, belajar mengenali, menghargai perasaan dalam diri mereka sendiri dan orang lain dan merespon dengan tepat serta efektif dalam menerapkan energi emosionalnya dalam kehidupan sehari-hari (Krisdyawati, 2017).

Tujuan dari pendidikan paling utama adalah mengembangkan dan mencerdaskan kehidupan bangsa seutuhnya, yaitu manusia yang berpengetahuan dan beriman, memiliki ketrampilan dan berakhlak, sehat secara jasmaniah dan ruhiah mempunyai kepribadian yang baik serta bertanggung jawab terhadap diri dan lingkungan disekitarnya dalam bermasyarakat. Pada umumnya pendidikan dasar dimulai dari keluarga, sikap, perilaku, ataupun sifat seseorang merupakan hasil dari didikan ayah dan ibu kepada anaknya sebab keluarga adalah sarana awal bagi anak untuk memulai mengenal proses kehidupan (Lubis, Daulay, Ahmad, \& Ali, 2020)

Semua orangtua mempunyai tujuan yang sangat baik untuk anaknya. Namun, kebanyakan orangtua tidak memahami dampak jangka panjang akibat dari pola asuh yang tidak tepat, perlu juga orangtua pahami dengan baik bahwa anak mempunyai keinginan yang sama seperti orang dewasa pada umumnya, (Francisca Firina Titahati, 2019). Lingkungan awal atau pertama dan utama anak ada didalam keluarga, oleh karena itu keluarga harus menyadari penuh akan hal tersebut. Orang tua memiliki peranan yang sangat vital dan menentukan bagi anak. Melalui arahan dan bimbingan dari orang tua akan dapat menentukan perkembangan dan masa depan anak. (Khalifah, 2018). Pola komunikasi membentuk kecerdasan emosi anak. Tingkat kecerdasan emosi seorang anak tidak terjadi begitu saja. Baik buruknya kecerdasan emosi anak tergantung dari bagaimana pola komunikasi orang tua tunggal yang diterapkan pada anak dalam keluarga (Putri, 2013). Dari beberapa penelitian menunjukan semakin demokratis pola asuh orangtua maka semakin tinggi tingkat kecerdasan emosional pada remaja. dan sebaliknya, semakin otoriter pola asuh orangtua maka semakin rendah tingkat kecerdasan emosionalnya (Amanda, 2016). Perkembangan emosi anak dari pola asuh demokratis yaitu anak yang dipenuhi dengan kasih sayang, cepat akur bersama orang sekitar seta anak lebih gampang akrab (Yulia Fahmi, 2020).

Namun sayang banyak orang tua yang tidak menyadari peran pola asuh orang tua adalah pengasuhan atau implementasi 
serangkaian keputusan yang dilakukan olah orang tua atau orang dewasa kepada anaknya sehingga memungkinkan anak menjadi bertanggung jawab, menjadi anggota masyarakat yang baik, serta memiliki karakter yang baik. Ada tujuh macam dimensi yang perlu ditumbuhkembangkan pada diri anak, yaitu fisik, akal, iman, akhlak, kewajiban, estetika dan social (Khamim Zarkasih Putro, 2015).

Dari uraian diatas, dapat dipahami terdapat beberapa faktor yang dapat mempengaruhi kecerdasan emosional anak. Selain itu banyak kasus permasalahan perkembangan emosional disebabkan orang tua tidak menyadari bahwa pola asuh dan komunikasi keluarga sangat berkontribusi terhadap perkembangan emosional anak, Maka tujuan penelitian ini adalah: melihat dampak komunikasi dalam keluarga dan pola asuh orangtua terhadap kecerdasan emosional anak usia 5-18 Tahun

\section{METODOLOGI PENELITIAN}

Penggunaan metode pada penelitian ini adalah Studi literature review, Jurnal yang digunakan dalam studi ini adalah jurnaljurnal yang membahas mengenai topik dengan kata kunci yaitu: pola asuh, komunikasi keluarga dan kecerdasan emosional pada anak usia 5 - 18 tahun. Penulisan sebanyak 72 tulisan artikel, yang terdiri dari 36 internasional dan 36 jurnal nasional setelah dilakukan seleksi sesuai kata kunci yang dianalisis 20 artikel, yang terdiri dari 7 artikel internasional dan 13 artikel Nasional penelusuran dengan mempergunakan google scholar dan sciencedirect dengan desain penelitian kuantitatif dan kualitatif, pada priode tahun 2010 - 2020 (Tabel 1).

\section{HASIL DAN PEMBAHASAN}

Berdasarkan penelusuran jurnal atau artikel yang sudah kami lakukan baik internasional dengan kategori Q1 sampai dengan Q4 dan Nasional Sinta 1 sampai Sinta 6 dengan kata kunci Pola asuh, komunikasi keluarga dengan kecedasan emosional pada anak, Kalau melihat dan membaca beberapa artikel internasional maupun nasional, bahwa pembentukan kecedasan emosinal anak sangat di pengaruh oleh cara orang tua memahami peran sebagai yang memberikan asuhan hingga anak terbentuk kecedasan emosional yang lebih baik, dan tidak kalah menariknya, tidak hanya cukup memberikan pola asuhan tapi juga frewensi atau lama komunikasi antara orang tua dan anak, sedangkan pada remaja juga sangat di pengaruh oleh teman sebaya atau lama mereka berkomunikasi analisis ini di dukung oleh penelitian yang dilakukan oleh (Amanda, 2016). selain penelitian diatas pola asuh, otoriter, demokratis, primitive berpengaruh sangat signifikan terhadap perkembangan kecerdasan emosional anak (Auliah, 2014).

\section{Komunikasi Keluarga Kecerdasan Emosional}

dengan

Penelitian lain juga mendukung bahwa pola komunikasi keluarga demokratis memiliki kecerdasan emosional yang lebih baik dibanding dengan komunikasi keluarga primisif (Hamdah, 2017). Dapat dijelas Kemampuan kecerdasan emosional tidak mudah untuk dimiliki, maka harus dilatihkan sejak dini, karena pada saat ini kecerdasan emosi sudah harus menjadi piranti penting bagi manusia dalam menempuh kehidupan yang sukses. Sama dengan begitu banyak orang tua "mampukah" untuk melatihkan (Khalifah, 2018). Biarpun dalam satu penelitian pola asuh otoriter berpengaruh terhadap perkembangan kecerdasan emosional anak disaran lebih baik dengan pola asuh yang demokratis akan lebih baik hasilnya untuk perkembangan emosional anak (Hariyanti, 2020). Semakin baik pola asuh orang tua kepada siswa dan semakin tinggi kecerdasan emosi siswa akan meningkatkan konsep diri siswa penelitian yang dilakukan oleh (Sutriyani, 2015).

\section{Pola Asuh Dengan Kecerdasan Emosional}

Kecedasan emosional dan kecedasan social merupakan tolak ukur keberhasil pola pengasuhan yang diberikan orang tua (Segrin \& Flora, 2019). Disisi lain pendidikan masih banyak menekan pada kecerdasan intelektual, siswa harus didorong mengenal diri mereka sendiri dan membimbing mereka ke konsep-konsep seperti kecerdasan emosional, keunggulan dan aplikasinya (Ghanimat, Koupahi, Partovian, \& Pashaei, 2013). Memberikan pelatihan kecerdasan intelektual ini akan membantu guru atau oran 
Tabel 1. Analisis Jurnal Internasional Dan Nasional

\begin{tabular}{|c|c|c|c|c|c|}
\hline No & $\begin{array}{c}\text { Nama Jurnal/ } \\
\text { penulis dan tahun } \\
\text { terbit }\end{array}$ & Judul Penelitian & Tujuan penelitian & Metodologi Penelitian & Hasil Penelitian \\
\hline 1 & $\begin{array}{l}\text { Jurnal Keperawatan } \\
\text { Komprehensif. } \\
\text { (Yuniar \& } \\
\text { Darmawati, 2015) }\end{array}$ & $\begin{array}{l}\text { Dukungan Keluarga } \\
\text { Berhubungan Dengan } \\
\text { Kecerdasan } \\
\text { Emosional Remaja }\end{array}$ & $\begin{array}{lr}\text { Penelitian ini dilakukan } \\
\text { untuk } & \text { mengetahui } \\
\text { adanya hubungan antara } \\
\text { dukungan } \\
\text { dengan keluarga } \\
\text { emosional remaja }\end{array}$ & $\begin{array}{l}\text { Deskriptif korelasi dengan } \\
\text { pendekatan cross sectional }\end{array}$ & $\begin{array}{l}\text { Terdapat hubungan yang sangat } \\
\text { rendah antara dukungan keluarga } \\
\text { dengan kecerdasan emosional } \\
\text { remaja SMA di Kota Bandung, maka } \\
\text { semakin tinggi dukungan keluarga } \\
\text { yang diperoleh maka semakin tinggi } \\
\text { pula kecerdasan emosional remaja. }\end{array}$ \\
\hline 2 & $\begin{array}{c}\text { Jurnal IImu } \\
\text { Komunikasi, } \\
\text { (Setyowati, 2005) }\end{array}$ & $\begin{array}{l}\text { Pola Komunikasi } \\
\text { Keluarga dan } \\
\text { Perkembangan Emosi } \\
\text { Anak (Studi Kasus } \\
\text { Penerapan Pola } \\
\text { Komunikasi Keluarga } \\
\text { dan Pengaruhnya } \\
\text { terhadap } \\
\text { Perkembangan Emosi } \\
\text { Anak pada Keluarga } \\
\text { Jawa) }\end{array}$ & $\begin{array}{l}\text { Mengetahui } r \text { bentuk } \\
\text { interaksi komunikasi } \\
\text { orang tua terhadap } \\
\text { perkekmbangan } \\
\text { emosional anak }\end{array}$ & $\begin{array}{l}\text { Jenis penelitian ini mengambil } \\
\text { strategi atau metode kualitatif } \\
\text { deskriptif }\end{array}$ & $\begin{array}{l}\text { Penerapan pola komunikasi } \\
\text { keluarga sebagai bentuk interaksi } \\
\text { antara orang tua dengan anak } \\
\text { maupun antaranggota keluarga } \\
\text { memiliki implikasi terhadap proses } \\
\text { perkembangan emosi anak. Dalam } \\
\text { proses komunikasi tersebut, anak } \\
\text { akan belajar mengenal dirinya } \\
\text { maupun orang lain, serta memahami } \\
\text { perasaannya sendiri maupun orang } \\
\text { lain. }\end{array}$ \\
\hline 3 & $\begin{array}{l}\text { Persona, Jurnal } \\
\text { Psikologi Indonesia } \\
\text { Januari 2014, Vol. 3, } \\
\text { No. 01, hal 1 - } 81\end{array}$ & $\begin{array}{lr}\text { Pola Asuh } & \text { Otoriter } \\
\text { Orang } & \text { Tua, } \\
\text { Kecerdasan } & \text { Emosi, } \\
\text { Dan Kemandirian } & \\
\text { Anak SD } & \end{array}$ & $\begin{array}{l}\text { Penelitian ini bertujuan } \\
\text { untuk mengetahui } \\
\text { hubungan antara pola } \\
\text { asuh otoriter orang tua } \\
\text { dan kecerdasan emosi } \\
\text { anak dengan } \\
\text { kemandirian. }\end{array}$ & $\begin{array}{l}\text { Data yang diperoleh dianalisis } \\
\text { dengan teknik analisis regresi } \\
\text { ganda }\end{array}$ & $\begin{array}{l}\text { Hasil penelitian menunjukkan bahwa } \\
\text { pola asuh otoriter dan kecerdasan } \\
\text { emosi berkorelasi dengan } \\
\text { kemandirian. Secara parsial hasil } \\
\text { penelitian juga menunjukkan adanya } \\
\text { korelasi negatif antara pola asuh } \\
\text { otoriter orang tua dengan } \\
\text { kemandirian. Sebaliknya, ada } \\
\text { korelasi positif antara kecerdasan } \\
\text { omosi dengan kemandirian. Kedua } \\
\text { variable dependent penelitian } \\
\text { memberikan kontribusi sekitar } 55,2 \% \\
\text { terhadap kemandirian anak }\end{array}$ \\
\hline
\end{tabular}




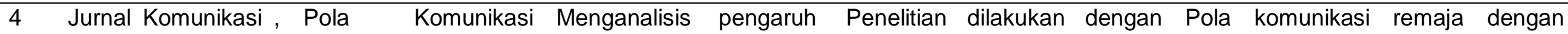
pola komunikasi remaja metode survei dan dianalisis keluarga, sekolah, dan teman Pengaruhnya dengan keluarga, menggunakan structural sebaya memberikan pengaruh Terhadap Kecerdasan sekolah, dan teman equation modeling (SEM). langsung dan nyata kepada Emosional Siswa Sma sebaya terhadap kecerdasan emosional siswa.. Pada Di Kota Bogor kecerdasan emosional siswa SMA di kota Bogor pola komunikasi remaja dengan sekolah, dimensi frekuensi pembicaraan yang paling besar kontribusinya. Sedangkan pada pola komunikasi remaja dengan teman sebaya, dimensi durasi pembicaraan memberikan kontribusi terbesar.

5 Jurnal Pendidikan Pengaruh Pola Asuh Penelitian ini bertujuan Metode kuantitatif deskriptif Anak,(Khamim Dan Interaksi Teman untuk mengetahui yaitu

Zarkasih Putro, Sebaya Terhadap pengaruh antara pola 2015) Kecerdasan asuh orang tua dan Emosional Anak Di interaksi antar teman Ra Arif Rahman sebaya terhadap Hakim Yogyakarta 1 kecerdasan emosional Khamim anak

Berdasarkan data yang diperoleh dari hasil analisis yang dilakukan dapat diperoleh kesimpulan sebagai berikut. Pertama, Terdapat pengaruh yang positif dari pola asuh orang tua terhadap kecerdasan emosional anak. Kedua, Terdapat pengaruh yang positif dari interaksi antar teman sebaya terhadap kecerdasan emosional anak. Ketiga, Terdapat pengaruh yang positif dari pola asuh orang tua dan interaksi antar teman sebaya secara bersama-sama (simultan) terhadap kecerdasan emosional anak,

\section{$6 \quad$ Jurnal}

Educatio,(Nisa,

Fakhriyah,

Masfuah, 2021)

\section{Hubungan Pola Asuh}

Dengan Kecerdasan

\& Emosional Anak Pada Usia 11-12 Tahun

\section{Penelitian}

untuk

hubungan pola asuh kecerdasan emosiona anak usia 11-12 tahun ini Hasil tersebut menunjukkan angka metode positif, nilai koefisien korelasi ( $r$ ) dengan termasuk dalam kategori sangat kuat desain berdasarkan pedoman interpretasi koefisien korelasi, sehingga dapat disimpulkan bahwa terdapat hubungan positif dan signifikan antara pola asuh orang tua terhadap kecerdasan emosional anak. 


\begin{tabular}{|c|c|c|c|c|c|}
\hline 7 & $\begin{array}{l}\text { Jurnal BUah Hati. } \\
\text { (Ayi Teiri Nurtiani, } \\
\text { 2018) }\end{array}$ & $\begin{array}{l}\text { Dampak Pola Asuh } \\
\text { Orangtua Terhadap } \\
\text { Kecerdasan } \\
\text { Emosional Anak Usia } \\
\text { 5-6 Tahun Di Tk Jasa } \\
\text { Bunda Aceh Besar }\end{array}$ & $\begin{array}{l}\text { Mengetahui dampak pola } \\
\text { asuh orangtua terhadap } \\
\text { kecerdasan emosional }\end{array}$ & $\begin{array}{l}\text { Metode penelitian adalah } \\
\text { penelitian kualitatif }\end{array}$ & $\begin{array}{l}\text { Hasil penelitian diperoleh bahwa } \\
\text { pola asuh yang diberikan orangtua } \\
\text { untuk mendidik anak di TK Jasa } \\
\text { Bunda adalah pola asuh demokratis } \\
\text { dan permisif dalam } \\
\text { mengembangkan kecerdasan } \\
\text { emosional anak usia 5-6 tahun }\end{array}$ \\
\hline 8 & $\begin{array}{lr}\text { IJEE, } & \text { (Luthfiyah } \\
\text { Triyani, } & \text { Tamsik } \\
\text { Udin, 2019) } & \end{array}$ & $\begin{array}{l}\text { Pengaruh Pola Asuh } \\
\text { Demokratis Orang } \\
\text { Tua Terhadap } \\
\text { Kecerdasan } \\
\text { Emosional Siswa } \\
\text { Kelas V Di Mi Al- } \\
\text { Hidayah Guppi Kota } \\
\text { Cirebon }\end{array}$ & $\begin{array}{l}\text { Penelitian ini bertujuan: } \\
\text { untuk mendeskripsikan } \\
\text { pola asuh terhadap } \\
\text { kecerdasan emosional }\end{array}$ & $\begin{array}{l}\text { Penelitian ini merupakan } \\
\text { penelitian kuantatif dengan } \\
\text { desain expost facto }\end{array}$ & $\begin{array}{l}\text { Hasil penelitian menunjukkan bahwa } \\
\text { pola asuh demokratis orang tua di } \\
\text { MI Al-Hidayah Guppi Kota Cirebon } \\
\text { sebesar } 87 \% \text { itu kategori sangat } \\
\text { kuat. Kemudian untuk kecerdasan } \\
\text { emosional siswa kelas V di Ml Al- } \\
\text { Hidayah Guppi Kota Cirebon } \\
\text { sebesar } 70 \% \text { itu kategori kuat }\end{array}$ \\
\hline 9 & $\begin{array}{l}\text { Jurnal } \quad \text { PAUD } \\
\text { Agapedia, (Sari \& } \\
\text { Mulyadi, 2020) }\end{array}$ & $\begin{array}{l}\text { Pola Asuh Orang Tua } \\
\text { Terhadap } \\
\text { Perkembangan } \\
\text { Emosional Anak Usia } \\
\text { Dini }\end{array}$ & $\begin{array}{l}\text { Tujuan artikel ini adalah } \\
\text { untuk meningkatkan } \\
\text { pemahaman tentang } \\
\text { pola asuh orang tua } \\
\text { terhadap perkembangan } \\
\text { emosional anak usia } \\
\text { dini,. }\end{array}$ & $\begin{array}{l}\text { Metodologi Penelitian Deskripsi } \\
\text { kualitatif }\end{array}$ & $\begin{array}{l}\text { Pola asuh yang diterapkan oleh } \\
\text { orang tua itu positif maka dampak } \\
\text { yang muncul pada anak pun akan } \\
\text { positif, akan tetapi sebaliknya jika } \\
\text { pola asuh yang diterapkan negatif } \\
\text { maka dampak pada perkembangan } \\
\text { emosional anak pun akan negatif. }\end{array}$ \\
\hline 10 & $\begin{array}{l}\text { Jurnal Pendidikan } \\
\text { Islam, (Lubis et al., } \\
\text { 2020) }\end{array}$ & $\begin{array}{l}\text { Upaya Orang } \\
\text { Mengembangkan } \\
\text { Kecerdasan } \\
\text { Emosional Anak } \\
\text { Dalam Keluarga } \\
\text { Muslim Di } \\
\text { Perkampungan } \\
\text { Kodam I/Bb Medan } \\
\text { Sunggal }\end{array}$ & $\begin{array}{l}\text { bertujuan untuk upaya - } \\
\text { upaya yang dilakukan } \\
\text { orang tua dalam } \\
\text { mengembangkan } \\
\text { kecerdasan emosional } \\
\text { anak }\end{array}$ & $\begin{array}{l}\text { Penelitian ini menggunakan } \\
\text { metodologi penelitian kualitatif } \\
\text { dengan pendekatan } \\
\text { fenomenologi, }\end{array}$ & $\begin{array}{l}\text { Upaya yang dilakukan orang tua } \\
\text { dalam mengembangkan kecerdasan } \\
\text { emosional anak dalam keluarga di } \\
\text { perkampungan KODAM I/BB Medan } \\
\text { Sunggal berpengaruh besar pada } \\
\text { perilaku dan pendidikan yang } \\
\text { diberikan oleh orang tua sejak awal } \\
\text { masa pertumbuhan anak, }\end{array}$ \\
\hline 11 & $\begin{array}{l}\text { British Journal of } \\
\text { Developmental } \\
\text { Psychology } \\
\text { (Gugliandolo, } \\
\text { Mavroveli, Costa, } \\
\text { Cuzzocrea, \& }\end{array}$ & $\begin{array}{lr}\text { The } & \text { relative } \\
\text { contribution } & \text { of } \\
\text { parenting practices in } \\
\text { predicting r trait } \\
\text { emotional intelligence } \\
\text { in an } \quad \text { Italian }\end{array}$ & $\begin{array}{l}\text { This study examines the } \\
\text { relationship between trait } \\
\text { emotional intelligence } \\
\text { (trait El), support, and } \\
\text { parental psychological } \\
\text { control practices. Three }\end{array}$ & $\begin{array}{l}\text { Three hundred pre-adolescents } \\
\text { between } 11 \text { and } 13 \text { years }\end{array}$ & $\begin{array}{l}\text { Tidak hanya pola asuh yang } \\
\text { pengaruh kecerdasan emosional } \\
\text { anak tapi peran orang tua, akan } \\
\text { berbeda pada anak wanita dan pria. }\end{array}$ \\
\hline
\end{tabular}

() Jurnal Kesehatan Perintis (Perintis's Health Journal)-ISSN : 2622-4135. All rights reserved 


\begin{tabular}{|c|c|c|c|c|c|}
\hline & Larcan, 2019) & adolescent sample & $\begin{array}{l}\text { hundred adolescents, } \\
\text { between } 11 \text { and } 13 \text { years } \\
\text { old, }\end{array}$ & & \\
\hline 12 & $\begin{array}{l}\text { Philadelphia College } \\
\text { of Osteopathic } \\
\text { Medicine } \\
\text { DigitalCommons@P } \\
\text { COM. (Farrell, 2015) }\end{array}$ & $\begin{array}{l}\text { The Relationship } \\
\text { Between Parenting } \\
\text { Style and the Level of } \\
\text { Emotional Intelligence } \\
\text { in Preschool-Aged } \\
\text { Children }\end{array}$ & $\begin{array}{l}\text { The purpose of this study } \\
\text { is to examine the } \\
\text { relationship between } \\
\text { parenting style and the } \\
\text { level of emotional } \\
\text { intelligence in preschool- } \\
\text { aged children }\end{array}$ & $\begin{array}{l}\text { The sample consisted of eighty } \\
\text { parent participants of } \\
\text { preschool-aged children } \\
\text { between the ages of } 3 \text { and } 6 \\
\text { years old. Participants } \\
\text { completed the Parenting Styles } \\
\text { and Dimensions Questionnaire } \\
\text { (PSDQ) }\end{array}$ & $\begin{array}{l}\text { Hasilnya menunjukkan bahwa ada } \\
\text { satu } \\
\text { hubungan signifikan ditemukan } \\
\text { secara khusus antara gaya } \\
\text { pengasuhan otoriter dan Tingkat } \\
\text { pengaruh negatif atau temperamen } \\
\text { negatif yang berhubungan dengan } \\
\text { emosional pada anak usia } \\
\text { prasekolah intelijen }\end{array}$ \\
\hline 13 & $\begin{array}{l}\text { NOVYI } \quad \text { MIR } \\
\text { Research Journal, } \\
\text { (Chitra, 2020) }\end{array}$ & $\begin{array}{lr}\text { Dynamics Of } & \text { Family } \\
\text { Structureon Emotional } \\
\text { Intelligence } & \text { Of } \\
\text { Secondary } & \text { School } \\
\text { Children } & \end{array}$ & $\begin{array}{l}\text { The current study } \\
\text { investigated the } \\
\text { moderating role of family } \\
\text { structure on the } \\
\text { Emotional Intelligence }\end{array}$ & $\begin{array}{l}\text { The current study investigated } \\
\text { the moderating role of family } \\
\text { structure on the Emotional } \\
\text { Intelligence among } 272 \\
\text { adolescents of both the gender } \\
\text { at age of } 16-18 \text { those who are } \\
\text { studying twelfth standard at } \\
\text { Salem district of Tamil Nadu. }\end{array}$ & $\begin{array}{l}\text { Peran struktur keluarga terutama } \\
\text { keluaraga intim berpengharuh pada } \\
\text { kecedasan emosional anak remaja }\end{array}$ \\
\hline 14 & $\begin{array}{l}\text { Psychology } \\
\text { Research and } \\
\text { Behavior } \\
\text { Management } \\
\text { (Tułecka, 2020). }\end{array}$ & $\begin{array}{l}\text { Family Functioning } \\
\text { and Life Satisfaction: } \\
\text { The Mediatory Role of } \\
\text { Emotional Intelligence }\end{array}$ & $\begin{array}{l}\text { The purpose of our study } \\
\text { was to examine the } \\
\text { association between } \\
\text { family functioning and life } \\
\text { satisfaction among } \\
\text { Polish adults. Moreover }\end{array}$ & $\begin{array}{l}\text { Methods and Data Collection: } \\
\text { The sample consisted of } 204 \\
\text { participants ( } 86 \% \text { women). We } \\
\text { measured family functioning, } \\
\text { satisfaction with life, and } \\
\text { emotional intelligence. The } \\
\text { data were collected using } \\
\text { online forums through } \\
\text { convenience sampling on the } \\
\text { basis of availability and the } \\
\text { willingness of the participants } \\
\text { to respond }\end{array}$ & $\begin{array}{l}\text { Fungsi keluarga yang baik dan } \\
\text { kepuasan hidup merupakan mediasi } \\
\text { dan membentuk kecedasan } \\
\text { emosional pada anak }\end{array}$ \\
\hline 15 & $\begin{array}{l}\text { Emotional } \\
\text { Intelligence And } \\
\text { Family Environment } \\
\text { (Dergisi, 2006) }\end{array}$ & $\begin{array}{l}\text { Emotional Intelligence } \\
\text { And } \\
\text { Environment }\end{array}$ & $\begin{array}{l}\text { The purpose of the study } \\
\text { to examine the } \\
\text { relationship between EQ } \\
\text { and family }\end{array}$ & $\begin{array}{l}\text { The sample of the study was } \\
\text { selected as } 274 \text { parents who } \\
\text { live in Istanbul including } 152 \\
\text { female, } 122 \text { male }\end{array}$ & $\begin{array}{l}\text { Hasil penelitian menunjukkan bahwa } \\
\text { terdapat hubungan antara } \\
\text { dengan } \\
\text { kerjasama keluarga }\end{array}$ \\
\hline
\end{tabular}

(c) Jurnal Kesehatan Perintis (Perintis's Health Journal)-ISSN : 2622-4135. All rights reserved 


\begin{tabular}{|c|c|c|c|c|c|}
\hline & & & environment & & \\
\hline 16 & $\begin{array}{l}\text { Fcp And Emotional } \\
\text { Intelligence } \\
\text { (Osredkar, 2012) }\end{array}$ & $\begin{array}{l}\text { The Relationship } \\
\text { Between Family } \\
\text { Communication } \\
\text { Patterns and an } \\
\text { Individual's Emotional } \\
\text { Intelligence }\end{array}$ & $\begin{array}{l}\text { This study in particular } \\
\text { focuses on the } \\
\text { relationship between } \\
\text { Family Communication } \\
\text { Patterns } \\
\text { emotional intelligence } \\
\text { and } \\
\text { personalization direct } \\
\text { conflict, an aspect of } \\
\text { Taking Conflict } \\
\text { Personally (TCP). }\end{array}$ & $\begin{array}{l}\text { Participants were found using } \\
\text { the snowball technique and } \\
\text { volunteer sampling with an } \\
\text { online survey tool, } \\
\text { surveygizmo.com. It was done } \\
\text { using three different strategies. } \\
\text { First, a Facebook event was } \\
\text { made where about one } \\
\text { hundred and fifty friends were } \\
\text { invited to participate. Second, } \\
\text { coworkers at the researcher's } \\
\text { internship were contacted by } \\
\text { email with the link of the } \\
\text { survey. They were asked to } \\
\text { pass the survey onto others. } \\
\text { Third, two professors } \\
\text { distributed the survey via email } \\
\text { to their classes. The survey } \\
\text { was anonymous. }\end{array}$ & $\begin{array}{l}\text { Studi ini ditemukan } \\
\text { personalisasi yang langsung dan } \\
\text { pola komunikasi keluarga yang } \\
\text { ditekankan } \\
\text { Percakapan itu sama-sama } \\
\text { berkaitan dengan aspek kecerdasan } \\
\text { emosional. }\end{array}$ \\
\hline 17 & $\begin{array}{l}\text { International Journal } \\
\text { Of Scientific \& } \\
\text { Technology } \\
\text { Research (S \& } \\
\text { Kadhiravan, 2019) }\end{array}$ & $\begin{array}{l}\text { Influence Of Family } \\
\text { Environment On } \\
\text { Emotional Intelligence } \\
\text { Among Youth }\end{array}$ & $\begin{array}{l}\text { Attempt is made to find } \\
\text { out the influence of } \\
\text { family environment on } \\
\text { emotional intelligence } \\
\text { among youth. }\end{array}$ & $\begin{array}{l}\text { Survey method was adopted in } \\
\text { this study. } 300 \text { Higher } \\
\text { Secondary School students } \\
\text { from six different schools in } \\
\text { Harur Taluk in Dharmapuri } \\
\text { District were selected through } \\
\text { stratified random sampling. }\end{array}$ & 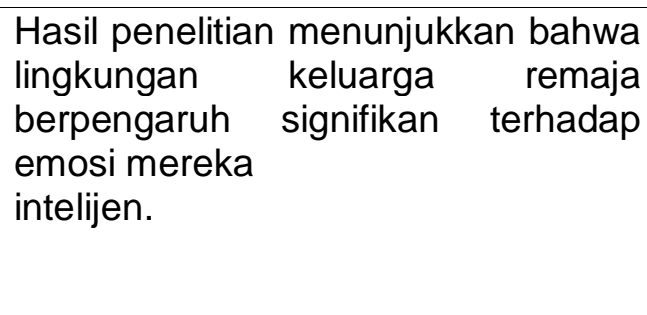 \\
\hline 18 & $\begin{array}{l}\text { Asian Journal of } \\
\text { Pediatric Research } \\
\text { (Olutope, C, \& A, } \\
2019 \text { ) }\end{array}$ & $\begin{array}{l}\text { Parenting Style, } \\
\text { Emotional Intelligence } \\
\text { and Psychological } \\
\text { Health of Nigerian } \\
\text { Children }\end{array}$ & $\begin{array}{l}\text { The influence of } \\
\text { parenting style on the } \\
\text { emotional intelligence } \\
\text { and psychological health } \\
\text { of the Nigerian child has } \\
\text { not being given adequate } \\
\text { research attention }\end{array}$ & $\begin{array}{l}\text { Exploratory /Descriptive survey } \\
\text { design. }\end{array}$ & 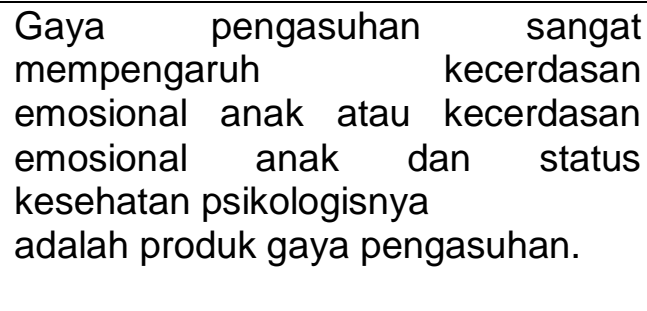 \\
\hline
\end{tabular}


tua yang memiliki anak cacat intelektual (Sheydaei, Adibsereshki, \& Movallali, 2015). Penelitian yang dilakukan di China menyatakan bahwa korelasi secara positif antara pola asuh dan komunikasi teman sebaya terhadap perkembangan kecerdasan emosional anak sekolah (Wang, Li, \& Zhu, 2019). Penelitian yang dilakukan di Iran juga mendukung penelitian diatas Kecerdasan emosional adalah prediktor pencapaian yang positif motivasi $(P<0,01)$ dan kecerdasan emosional memainkan mediator parsial antara orientasi percakapan keluarga dan konformitas orientasi dengan motivasi berprestasi (Abbasiasl, Naderi, \& Akbari, 2017).

Pembentukan kecerdasan emosional akan lebih baik terbukti dengan penelitian yang dilakukan di Jordan dukungan emosional yang tinggi baik dari keluarga guru dan teman sebaya akan memberikan kontribusi yang signifikan dalam variasi emosional intelijen (Atoum, 2018). Penelitian yang dilakukan di Amerika menyatakan pola komunikasi langsung dan komunikasi keluarga sangat membantu perkembangan kecedasan emosinal anak (Osredkar, 2012). Penelitian yang dilakukan di Iran memperkuat peran keluarga, semakin tinggi fungsi keluarga maka semakin tinggi pula sifat kecerdasan emosionalnya dikalangan remaja (Alavi, Mehrinezhad, Amini, Kaur, \& Singh, 2017). Perlu menjadi perhatikan dalam memberikan berkomunikasi dalam keluarga bahwa peran ayah sangat mempengaruh Intelegensi emosinal seorang anak penelitian yang diulakukan oleh (Biggart, Corr, Brien, \& Cooper, 2010). Komunikasi yang positif merupakan sebahagian besar memperkuat kecedasan emosional seorang anak (Paula, Montero-montero, \& Moreno-ruiz, 2019). Berdasarkan penelitian yang dilakukan di USA ada 4 hal penting yang harus diperhatikan yang dapat mempengaruhi kecerdasan emosional anak, 1. Respon positif orang tua, 2. Daya tanggap orang tua, tuntutan orang tua, dan program intervensi pendukung yang dilakukan di sekolah untuk meningkatkan keterampilan emosional anak (Alegre, 2014).

Penelitian yang dilakukan di Kaunas Lithuania menyebutkan kecerdasan emosional seseorang dipengaruh secara signifikan pada iklim psikologis dalam keluarga, kekuatan hubungan subjek dengan ibu / ayah, persepsi subjektif tentang status keuangan keluarga
(Lekaviciene \& Antiniene, 2016). Pada penelitian lain dapat di bukti bahwa ada korelasi langsung antara kecedasan emosi anak dan orang tua (Ǵ \& Tulbure, 2014). Orang tua yang mendidik anak dengan berupaya mengembangkan emosional (EQ) melalui kemampuan yang dimiliki anak untuk mengenali emosi diri sendiri, mengelolah emosi secara baik, rasa simpati, mampu berkomunikasi dengan baik, memiliki rasa empati yang tinggi, akan menjadi poin-poin penting bagi ayah dan ibu (keluarga) untuk menjadikan anak sukses dalam perjalanan hidup anak.

\section{KESIMPULAN}

Dari hasil penelusuran literature yang di baca bahwa dari 3 teori pola asuh semua berpengaruh pada tingkat kecerdasan emosional anak, namun pola asuh demokratis, memberikan peluang besar anak memiliki kesempatan untuk berkomunikasi dan pikiran, serta belajar menempatkan diri pada tempat orang lain, didukung dengan komunikasi keluarga yang baik. Penerapan pola komunikasi keluarga sebagai bentuk interaksi antara orang tua dengan anak maupun antara anggota keluarga memiliki implikasi terhadap proses perkembangan emosi anak. Saran setiap orang tua harus menjaga komunikasi dan memberikan pola asuh yang baik karena akan berkontribusi secara penuh terhadap perkembangan kecerdasan emosional anak.

\section{UCAPAN TERIMA KASIH}

Penulis menyampaikan terima kasih kepada Rektor Universitas Fort De Kock dan Institut Agama Islam Negeri Bukittinggi yang telah memberi waktu dalam melakukan penelitian

\section{REFERENSI}

Abbasi-asl, R., Naderi, H., \& Akbari, A. (2017). Mediating Role of Emotional Intelligence Between Family Communication Patterns and Achievement Motivation Among High School Students. School Health, 4(3), 1-7. https://doi.org/10.5812/intjsh.41910.Resea rch

Alavi, M., Mehrinezhad, S. A., Amini, M., Kaur, M., \& Singh, P. (2017). Family functioning and trait emotional intelligence among youth. Health Psychology Open, 1(5), 1-5. https://doi.org/10.1177/205510291774846 
1

Alegre, A. (2014). Parenting Styles and Children ' s Emotional. The Family Journal, (January 2011). https://doi.org/10.1177/106648071038748 6

Amanda, D. S. (2016). Hubungan Pola Asuh Orangtua Terhadap Pembentukan Kecerdasan Emosional Pada Remaja Di SMK Negeri 8 Jakarta Title. Universitas Pembagunan Nasional"Veteran" Jakarta.

Atoum, A. (2018). Emotional support and its relationship to Emotional intelligence. Advances in Social Sciences Research Journal, 5(1), 7-11. https://doi.org/10.14738/assrj.51.4095

Auliah, D. (2014). Studi Komparasi Kecerdasan Emosional Berdasarkan Pola Asuh Orang Tua Pada Anak Usia Prasekolah Di TK Kuncup Mekar Tegalmulyo Yogyakarta. Stikes Aisyiyah Yogyakarta.

Ayi Teiri Nurtiani, C. M. (2018). Dampak Pola Asuh Orangtua Terhadap Kecerdasan Emosional Anak Usia 5-6 Tahun Di TK Jasa Bunda Aceh Besar. Jurnal Buah Hati, 5(1), 14-20.

Biggart, L., Corr, P., Brien, M. O., \& Cooper, N. (2010). Trait emotional intelligence and work - family conflict in fathers. Personality and Individual Differences, 48(8), 911-916. https://doi.org/10.1016/j.paid.2010.02.020

Chitra, A. (2020). Dynamics of family structureon emotional intelligence of dynamics of family structureon emotional. Novyi MIR Research Journal, 5(5), 105115.

Cooper RK \& Ayman Sawaf. 2005. Executive EQ: Kecerdasan Emosional dalam Kepemimpinan dan Organisasi. Jakarta: PT Gramedia Pustaka Utama

Dergisi, S. B. (2006). Emotional intelligence and family environment. Emotional Intelligence and Family Environmen, 16, 169-175.

Farrell, G. (2015). The Relationship Between Parenting Style and the Level of Emotional Intelligence in Preschool-Aged Children. Philadelphia College of Osteopathic Medicine DigitalCommons@PCOM.

Francisca Firina Titahati. (2019). Jurnal Bimbingan dan Konseling Indonesia Vol 4 No 1 , Maret 2019 Pengaruh Konseling Trait And Factor Dan Pola Asuh Orang Tua Terhadap Kecerdasan Emosi (
Emotional Jurnal Bimbingan dan Konseling Indonesia Vol 4 No 1 , Maret 2019. Bimbingan Dan Konslng Indonesia, 4(1), 1-9.

G, A. T., \& Tulbure, C. (2014). The relation between the emotional intelligence of parents and children. Procedia - Social and Behavioral Sciences, 142, 592-596. https://doi.org/10.1016/j.sbspro.2014.07.6 71

Ghanimat, P., Koupahi, M., Partovian, S., \& Pashaei, K. (2013). Analysis Of The Relationship Between Demographic Characteristics And Emotional Intelligence In Female Student ( Case Study: Islamic Azad University of Tabriz ). Kuwait Chapter of Arabian Journal of Business and Management Review, 2(5), 5-16.

Gugliandolo, M. C., Mavroveli, S., Costa, S., Cuzzocrea, F., \& Larcan, R. (2019). The relative contribution of parenting practices in predicting trait emotional intelligence in an Italian adolescent sample. British Journal of Developmental Psychology, 37, 585-599.

https://doi.org/10.1111/bjdp.12299

Hamdah, H. (2017). Pengaruh Keharmonisan Keluarga Dan Pola Asuh Orang Tua Terhadap Kecerdasan Emosional (EQ) Siswa Kelas VIII MTsN Karangmojo II Magetan. Institut Agama Islam Negeri Ponorogo.

Handayani, N., \& Fauziah, N. (2016). Emosional Pada Guru Bersertifikasi Sekolah Menengah Atas Swasta Berakreditasi " A " Wilayah Semarang Barat. Jurnal Empati, 5(April), 408-412.

Hariyanti, N. M. S. dan D. (2020). Hubungan Antara Pola Asuh Otoriter Orang Tua Dengan Kecerdasan Emosional Anak Kelompok B Di PAUD Taman Bangsa Gegutuno Title. Jurnal Realita, 5(April), 967-971.

Khalifah. (2018). Pengaruh Pola Asuh Orang Tua Terhadap Kecerdasan Emosional Aud TK Muslimat NU 1 Tuban. Jurnal Pendidikan Anak, 7(1), 61-75.

Khamim Zarkasih Putro. (2015). Pengaruh Pola Asuh Dan Interaksi Teman Sebaya Terhadap Kecerdasan Khamim Zarkasih Putro. Jurnal Pendidikan Anak, 1(2), 97108.

Krisdyawati, R. C. (2017). Pengaruh antara kecerdasan emosional terhadap komunikasi. Mihammadiyah Malang.

Lekaviciene, R., \& Antiniene, D. (2016). High 
emotional intelligence: family psychosocial factors. Procedia - Social and Behavioral Sciences, 217, 609-617. https://doi.org/10.1016/j.sbspro.2016.02.0 66

Lubis, S. A., Daulay, N., Ahmad, J., \& Ali, R. (2020). Emosional Anak Dalam Keluarga Muslim Di Perkampungan Kodam I / BB Medan SunggaL Abstrak Pendahuluan Tujuan dari pendidikan paling utama adalah mengembangkan dan mencerdaskan kehidupan bangsa seutuhnya , yaitu manusia yang berpengetahuan dan sehat secara $\mathrm{j}$. Jurnal Pendidikan Islam, 09(02), 573-582.

Luthfiyah Triyani, Tamsik Udin, H. (2019). Pengaruh Pola Asuh Demokratis Orang Tua Terhadap Kecerdasan Emosional Siswa Kelas V DI MI AL-Hidayah GUPPI Kota Cirebon. IJEE, 1(1).

Nisa, K., Fakhriyah, F., \& Masfuah, S. (2021). Hubungan Pola Asuh Dengan Kecerdasan Emosional Anak Pada Usia 11-12 Tahun. Jurnal Educatio, 7(1), 55-63. https://doi.org/10.31949/educatio.v7i1.830

Novi Eka Jayanti, S. M. J. S. (2019). Hubungan Antara Keharmonisan Keluarga Dan Kecerdasan Emosi Dengan Kecenderungan Perilaku Delinkuen Pada Siswa SMK Adi Luhur 2 Jakarta TIMURNO Title. Ikraith-Humaniora, 3(2), 46-51.

Olutope, A. E., C, A. B., \& A, O. O. (2019). Parenting Style, Emotional Intelligence and Psychological Health of Nigerian Children. Asian Journal of Pediatric Research, 2(2), 1-11. https://doi.org/10.9734/AJPR/2019/v2i230 100

Osredkar, P. (2012). The Relationship Between Family Communication Patterns and an Individual ' $s$ Emotional Intelligence. FCP Emotional Intelligence, 1-32.

Paula, L., Montero-montero, D., \& Moreno-ruiz, D. (2019). behavioral sciences The Role of Parental Communication and Emotional Intelligence in Child-to-Parent Violence. Behavioral Sciences, 9(148), 2-13.

Putri, W. (2013). Pola komunikasi orang tua tunggal dalam membentuk kecerdasan emosi remaja skripsi. Universitas Pembangunan Nasional.

S, J. R., \& Kadhiravan, S. (2019). Influence Of Family Environment On Emotional Intelligence Among Youth. International
Journal Of Scientific \& Technology Research, 8(11), 3664-3670.

Sari, P. P., \& Mulyadi, S. (2020). Pola Asuh Orang Tua Terhadap Perkembangan Emosional Anak Usia Dini. Jurnal PAUD Agapedia, 4(1), 157-170.

Segrin, C., \& Flora, J. (2019). Fostering social and emotional intelligence: What are the best current strategies in parenting? WILEY, 1-14. https://doi.org/10.1111/spc3.12439

Setyowati, Y. (2005). Pola Komunikasi Keluarga dan Perkembangan Emosi Anak ( Studi Kasus Penerapan Pola Komunikasi Keluarga dan Pengaruhnya terhadap Perkembangan Emosi Anak pada Keluarga Jawa ). IImu Komunikasi, 2(1), 67-78.

Sheydaei, M., Adibsereshki, N., \& Movallali, G. (2015). Archive of SID The Effectiveness of Emotional Intelligence Training on Communication Skills in Students with Intellectual Disabilities Archive of SID. Iranian Rehabilitation Journal, 13(3), 7-13.

Sutriyani, A. (2015). Hubungan antara pola asuh orang tua dan kecerdasan emosi dengan konsep diri siswa kelas viii sekolah menengah pertama negeri 2 mlati di sinduadi mlati sleman tahun pelajaran 2014/2015. Universitas PGRI Yogyakarta 2015.

Tułecka, M. S. M. (2020). Family Functioning and Life Satisfaction: The Mediatory Role of Emotional Intelligence. Psychology Research and Behavior Management, 13, 223-232.

Wang, Y., Li, Z., \& Zhu, L. (2019). Emotional intelligence of 3- to 6-year-olds and parenting style: Peer communication ability as a mediator. Sosial Behavior and Personality, 47(12).

Yulia Fahmi. (2020). Pola Asuh Ibu Yang Menikah Diusia Muda Dalam Perkembangan Emosional Pada Anak Usia Dini. Universitas Pendidikan Indonesia.

Yuniar, D., \& Darmawati, I. (2015). Kecerdasan Emosional Remaja. Jurnal Keperawatan Komprehensi, 033(1), 9-17. 